\title{
Role of agr (RNAIII) in Staphylococcus aureus adherence to fibrinogen, fibronectin, platelets and endothelial cells under static and flow conditions
}

\author{
BORIS SHENKMAN, DAVID VARON, ILIA TAMARIN, RIMA DARDIK, MARTHA PEISACHOV*, \\ NAPHTALI SAVION† and ETHAN RUBINSTEIN*
}

Institute of Thrombosis and Hemostasis, *Infectious Diseases Unit, Sheba Medical Center, Tel Hashomer and $\uparrow$ Goldschleger Eye Research Institute, Tel Aviv University, Tel Aviv, Israel

\begin{abstract}
In the present study, the adherence of Staphylococcus aureus (strain 8325-4) and its RNAIII mutant (WA400) to immobilised fibrinogen and fibronectin, and to human endothelial cells (EC), was studied. $\left[{ }^{3} \mathrm{H}\right]$ Thymidine-labelled bacteria in stationary phase were incubated on the test surfaces for 20 min under static or flow $(200 / \mathrm{s})$ conditions. The results showed: (a) increased adherence of the RNAIII mutant to fibrinogen under static conditions, and decreased adherence of the mutant to fibronectin and EC under both static and flow conditions compared with the parental strain; (b) stronger ability of the mutant compared with the parental strain to induce platelet aggregation in suspension; (c) greater adherence of the parental strain and the mutant to EC pretreated with platelet-rich plasma compared with platelet-poor plasma, and to EC pretreated with platelet-poor plasma compared with control; (d) increased adherence of $S$. aureus to EC pre-treated with PMA-activated platelets and decreased adherence to EC pre-treated with tirofiban, a platelet glycoprotein IIb-IIIa inhibitor, which paralleled with increased adherence of PMA-activated platelets and decreased adherence of glycoprotein IIb-IIIa-blocked platelets to EC in the absence of bacteria; and (e) adherence of the mutant was more sensitive to pre-treatment of EC with plasma and PMA-activated platelets. In conclusion, RNAIII down-regulates $S$. aureus adherence to fibrinogen under static condition and up-regulates $S$. aureus adherence to fibronectin and EC under both static and flow conditions. The potentiating role of activated platelets in the presence of plasma in $S$. aureus adherence to EC is down-regulated by RNAIII, probably due to down-regulation of adherence to fibrinogen, the important plasma protein bridging $S$. aureus, platelets and EC.
\end{abstract}

\section{Introduction}

Adherence of Staphylococcus aureus to the host tissues is dependent on the expression of the bacterial cell wall-associated proteins of the so-called microbial surface components recognising adhesive matrix molecules (MSCRAMM) family [1]. Various bacterial surface proteins associated with adherence have been characterised at the molecular level, such as Cna for collagen, FnbpA and FnbpB for fibronectin, and ClfA and ClfB for fibrinogen [2-4]. Protein A has been found to bind to the Fc domain of $\operatorname{IgG}$ and to mediate

Received 3 Dec. 2001; revised version received 21 Feb. 2002; accepted 16 April 2002.

Corresponding author: Dr E. Rubinstein (e-mail: unit@, netvision.net.il). attachment of $S$. aureus to von Willebrand factor [5]. $S$. aureus can also bind to other plasma proteins and extracellular matrix components.

Many of the virulence determinants of $S$. aureus are regulated by agr and sar global regulatory systems. The agr locus acts at both transcription and translation to regulate the production of numerous toxins, enzymes and cell surface proteins [6, 7]. Agr is composed of two divergent transcripts, RNAII and RNAIII, initiated from P2 and P3 promoters, respectively [8]. A second regulatory locus, sar, is essential for $a g r$-dependent regulation. It is believed that $a g r$ activation is partially mediated by the binding of sar gene products to the agr promoter stimulating the transcription of RNAII and RNAIII [9]. Recent studies have shown that sar can bind to the $\mathrm{P} 2$ promoter region regulating agr- 
mediated exoprotein production [10,11]. During the exponential growth of bacteria, the sar and agr systems organise cell metabolism to ensure efficient growth rate [12]. At the post-exponential phase, other virulence factors are governed by global regulatory systems. During growth, the actual effector RNAIII significantly increases transcription of various genes [13].

Platelets play an important role in the pathogenesis of infective endocarditis and endovascular infection by providing an adhesive surface for bacterial binding on the vessel wall [14]. S. aureus binds directly to naive platelets causing platelet aggregation that results in formation of infected vegetation [15]. Moreover, in experimental endocarditis, anti-platelet agents cause substantial reduction in vegetation weight [16]. However, platelet aggregation may protect bacteria from exposure to antibiotics or clearance by leucocytes [17]. Stimulated platelets contain an array of microbicidal peptides [18] and generate a profile of molecules that mediate oxidative killing [19]. The role of platelets in S. aureus infection is not fully understood.

The purpose of the present study was to report the role of RNAIII in adherence of $S$. aureus to immobilised fibrinogen and fibronectin, and to cultured endothelial cells EAhy.926 (EC) under both static and flow conditions $(200 / \mathrm{s})$. The promoting role of platelets in bacterial adherence to EC and the contribution of RNAIII to this process were also investigated.

\section{Materials and methods}

\section{Bacterial strains}

The $S$. aureus strains used were 8325-4, a laboratory strain and WA400, an RNAIII mutant of this strain in which the RNAIII gene is deleted and replaced by the cat86 gene [20]. The RNAIII mutant has a pattern similar to that of an $\operatorname{agr} \mathrm{A}$ mutant.

\section{Preparation of bacteria}

S. aureus was grown overnight at $37^{\circ} \mathrm{C}$ on Mannitol Salt Agar (BBL/11407), harvested and incubated at $37^{\circ} \mathrm{C}$ in tryptone soy broth overnight aerobically to stationary phase. For radiolabelling, [methyl $-{ }^{3} \mathrm{H}$ ] thymidine $(1 \mu \mathrm{Ci} / \mathrm{ml})$ (NEN, Boston, USA) was added to $S$. aureus $1 \times 10^{8} \mathrm{cfu} / \mathrm{ml}$ suspended in tryptone soy broth and incubated overnight. The specific activity of the labelled $S$. aureus was $12500 \mathrm{cpm} / 10^{8}$ cells. Cells were washed three times with phosphate-buffered saline (PBS) (final volume $3 \mathrm{ml}$ ) and mixed vigorously. The bacterial count was determined by optical density at $546 \mathrm{~nm}$ with a standard suspension (MacFarland $2=6 \times 10^{8}$ cells $/ \mathrm{ml}$ ) and the bacterial inoculum was confirmed by colony counts. The bacterial count was adjusted to $1.0 \times 10^{9} \mathrm{cfu} / \mathrm{ml}$ and used shortly thereafter. Under these conditions, there was no bacterial clumping.

\section{Pre-coating of polystyrene plates with fibrinogen and fibronectin}

Human fibrinogen (Sigma) was passed through a gelatine-sepharose column to remove residual fibronectin [3]. Purified bovine fibronectin was purchased from Biological Industries (Beit Haemek, Israel). The proteins were dissolved in PBS in the presence of bovine serum albumin (BSA; Sigma) $0.1 \%$ in the following concentrations: fibrinogen 0.5 and $2.0 \mathrm{mg} /$ $\mathrm{ml}$, and fibronectin $10 \mu \mathrm{g} / \mathrm{ml}$, as used in a previous study [21]. However, it should be taken into account that the relatively high fibrinogen and fibronectin concentrations reflect the physiological concentrations of the proteins in plasma and are relevant when the proteins are in a complex mixture where the amount of specific protein bound to plastic surface will be much lower than when the purified protein is used in vitro. Protein solutions were exposed to four-well polystyrene tissue-culture plates (Nunc, Roskilde, Denmark) at room temperature for $2 \mathrm{~h}$. After washing with PBS containing BSA $0.1 \%$, plates were further incubated with PBS-BSA $1 \%$ for $1 \mathrm{~h}$ to block the remaining free non-specific binding sites on the surface. Coated plates were held at $4^{\circ} \mathrm{C}$ for no more than 7 days before use.

\section{Preparation of endothelial cells}

Human endothelial cell line EAhy.926 [22] was cultured in four-well tissue culture plates in Dulbecco's modified Eagle's medium supplemented with fetal calf serum $10 \%$, hypoxanthine-aminopterin-thymidine supplement (100 $\mu \mathrm{M}$ sodium hypoxanthine, $400 \mathrm{nM}$ aminopterin and $16 \mu \mathrm{M}$ thymidine), $2 \mathrm{mM}$ glutamine, penicillin $100 \mathrm{U} / \mathrm{ml}$, streptomycin $0.1 \mathrm{mg} / \mathrm{ml}$ and nystatin $12.5 \mathrm{U} / \mathrm{ml}$. The cells were grown until a confluent monolayer was obtained. Before assay, plates were gently washed twice with PBS. The integrity of the EC monolayer at the end of the experiment was confirmed by inverted phase microscopy. All experiments were conducted at $37^{\circ} \mathrm{C}$.

\section{S. aureus adherence to immobilised fibrinogen and fibronectin, and to endothelial cell monolayer}

A suspension of $2 \times 10^{8}$ cfu $\left[{ }^{3} \mathrm{H}\right]$ thymidine-labelled $S$. aureus (total volume $200 \mu \mathrm{l}$ ) was placed on PBS-BSA $0.1 \%$ washed plates and incubated for $20 \mathrm{~min}$ at $37^{\circ} \mathrm{C}$ under static (light oscillation) or flow $(200 / \mathrm{s})$ conditions. Flow was created by a rotating teflon cone, originally designed to evaluate platelet adhesion and aggregation [22]. After incubation, wells were gently washed twice with PBS. Bound cells were solubilised in SDS $2 \%$ and the samples were counted in a $\beta$ scintillation counter (Liquid Scintillation Analyser 1600-TR, Packhard, USA). All experiments were conducted in duplicate. 
Preparation of platelet-rich plasma (PRP), platelet-poor plasma (PPP) and $\left[{ }^{3} \mathrm{H}\right]$ adeninelabelled platelets

Peripheral vein blood was obtained from healthy volunteers who had not taken medications known to affect platelet function for at least 10 days before blood sampling. The blood was collected in polypropylene tubes (sodium citrate $3.8 \%$ anticoagulant:blood ratio 1:9) and centrifuged at $160 \mathrm{~g}$ for $12 \mathrm{~min}$ to produce an upper PRP suspension; the suspension was collected. The remaining blood was centrifuged at $1800 \mathrm{~g}$ for 12 min to produce PPP which was also collected. For labelling of platelets, PRP was incubated with $\left[{ }^{3} \mathrm{H}\right]$ adenine $5 \mu \mathrm{Ci} / \mathrm{mL}$ for $30 \mathrm{~min}$ at room temperature followed by addition of citric acid to a final concentration of $5 \mathrm{mM}$, centrifuged at $800 \mathrm{~g}$ for $8 \mathrm{~min}$, washed and resuspended to the original volume in autologous PPP.

\section{Platelet adhesion experiments}

Non-labelled or $\left[{ }^{3} \mathrm{H}\right]$ adenine-labelled platelets in autologous citrated plasma - $200 \mu \mathrm{l} /$ well containing $(2-4) \times 10^{7}$ platelets - were pre-treated for $20 \mathrm{~min}$ with PBS-BSA $0.1 \%, 1 \mu \mathrm{M}$ phorbol 12-myristate 13acetate (PMA), $1 \mu \mathrm{M}$ prostaglandin $\mathrm{E}_{1} / 100 \mu \mathrm{M}$ isobutyl-methyl-xantine ( $\left.\mathrm{PGE}_{1} / \mathrm{IBMX}\right)$ (all from Sigma) or $0.15 \mu \mathrm{M}$ tirofiban (Merck, Darmstadt, Germany). Platelets were resuspended in autologous plasma and incubated with EC under flow condition $(200 / \mathrm{s})$ for $20 \mathrm{~min}$ at $37^{\circ} \mathrm{C}$. Unbound platelets were gently removed by washing with PBS. In experiments with radiolabelled platelets, bound cells were solubilised in SDS $2 \%$. The radioactivity of the samples was counted in the $\beta$-scintillation counter.

\section{S. aureus-induced platelet aggregation}

Platelet aggregation was monitored by a standard technique in which $225 \mu \mathrm{l}$ of PRP were incubated at $37^{\circ} \mathrm{C}$ and stirred at $1000 \mathrm{rpm}$ in a PACKS-4 fourchannel aggregometer (Helena Lab., PACKS-4, Beaumont, TX, USA). Aggregation was induced by adding $25 \mu 1$ of $S$. aureus suspension in PBS (bacteria:platelet ratio 4:1). The change in light transmission was recorded for $20 \mathrm{~min}$. The lag phase and the maximal aggregation extent were considered. In separate experiments, PRP was incubated with $1.0 \mu \mathrm{M}$ prostaglandin $\mathrm{E}_{1}$ before addition of bacteria.

\section{Statistical analysis}

Statistical analysis was performed by unpaired twotailed $t$ test with $\mathrm{p}<0.05$ regarded as significant. GraphPad Prism Software was used.

\section{Results}

\section{S. aureus adherence to immobilised fibrinogen and fibronectin, and to EC monolayer}

Under static conditions, there was a significant increase in adherence of the RNAIII mutant, compared with the parent strain, to fibrinogen used at 0.5 and $2.0 \mathrm{mg} / \mathrm{ml}$ for coating the polystyrene surface (by c. $40 \%$ and $50 \%$, respectively) (Fig. 1a). However, no difference was found under flow conditions. Decreased adherence to fibronectin of the RNAIII mutant was observed under both static and flow conditions (by 35\% and $45 \%$, respectively) (Fig. 1b). No substantial differences were observed in bacterial adherence to both protein ligands under static and flow conditions. A substantial reduction (c. 50\%) in adherence to $\mathrm{EC}$ monolayer of the RNAIII mutant compared with the parent strain was shown under both static and flow conditions (Fig. 1c). Adherence of both $S$. aureus strains to EC was 2.5-fold higher under static than under flow conditions. The data shown in Fig. 1 suggest that RNAIII decreases bacterial adherence to fibrinogen under static conditions, whereas it increases bacterial adherence to fibronectin and EC under both static and flow conditions.

\section{S. aureus-induced platelet aggregation}

The ability of $S$. aureus to aggregate platelets in PRP after a 4-8 min lag phase was demonstrated (Fig. 2). The RNAIII mutant had a stronger effect than the parent strain on the length of the lag phase and the extent of maximal aggregation. These data correlate with those in Fig. 1a showing increased adherence of the RNAIII mutant to fibrinogen-coated surface, suggesting that platelet aggregation by $S$. aureus requires binding to fibrinogen [24]. Pre-incubation of PRP with prostaglandin $\mathrm{E}_{1}$ prevented $S$. aureus-induced aggregation (data not shown).

\section{Relative role of plasma ligands and platelets in $S$. aureus adherence to $E C$}

In this assay, EC monolayers were pre-incubated with PBS, PPP or PRP before incubation with $S$. aureus. As shown in Fig. 3, pre-incubation of EC with PPP resulted in an increased binding of both parent $S$. aureus and RNAIII mutant strains compared with their binding to non-treated EC (1.5- and 4.5-fold, respectively). When EC were pre-incubated with PRP, adherence of both types increased further (4- and 6.3fold, respectively).

In the subsequent experiments, modulation of platelet function (in PRP) was conducted. $\mathrm{PGE}_{1} / \mathrm{IBMX}$ was used to inactivate platelets by increasing the intracellular cAMP level [25], PMA as an activator of protein kinase C [26] and tirofiban (a non-peptidic Arg-GlyAsp analogue) as a blocker of platelet glycoprotein IIbIIIa [27]. Pre-treatment of EC with $\mathrm{PGE}_{1} / \mathrm{IBMX}$ 


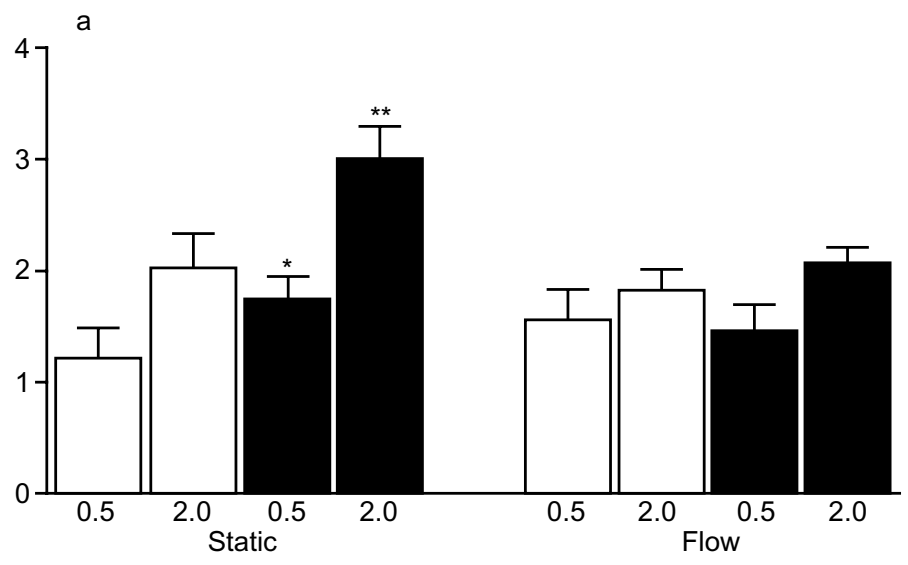

b
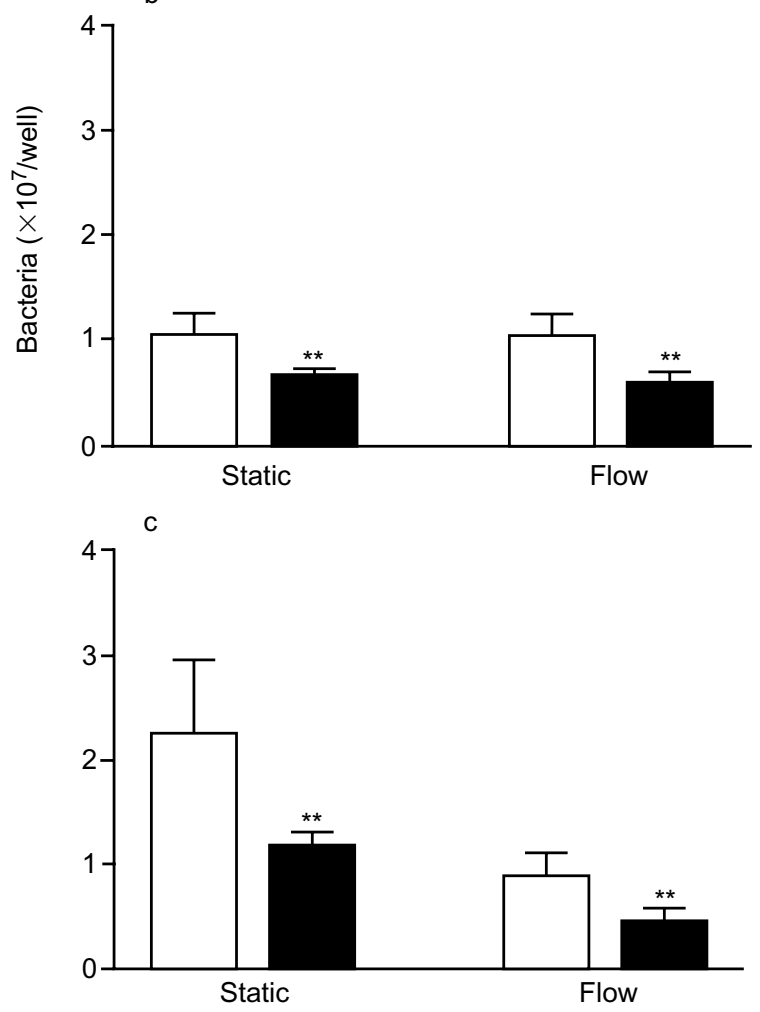

Fig. 1. Adherence of $S$. aureus to immobilised (a) fibrinogen, (b) fibronectin and (c) EC monolayer. Parental strain (8325-4; $\square$ ) and RNAIII $^{-}$mutant (WA400; $\left.){ }^{3} \mathrm{H}\right]$ thymidine labelled $S$. aureus $\left(2 \times 10^{8} \mathrm{cfu}\right)$ were placed on polystyrene tissue-culture plates, pre-coated with fibrinogen $(0.5$ and $2.0 \mathrm{mg} / \mathrm{ml})$, fibronectin $(0.01 \mathrm{mg} / \mathrm{ml})$, or EC monolayer and incubated under static (light oscillation) or flow $(200 / \mathrm{s})$ conditions for $20 \mathrm{~min}$ at $37^{\circ} \mathrm{C}$. Samples were washed and adherent bacteria were solubilised with SDS $2 \%$. Data are mean and SD of four or five determinations performed in duplicate. ${ }^{*} \mathrm{p}<0.01$ and ${ }^{* *} \mathrm{p}<0.001$ for the mutant compared with the parental strain.

inactivated platelets did not alter adherence of both $S$. aureus strains to EC compared to pre-treatment of EC with non-treated PRP (Fig. 3). However, pre-treatment of EC with PMA-activated platelets resulted in substantial enhancement in adherence of both parental strain and RNAIII mutant (1.7- and 4-fold, respectively). In contrast, a blockade of platelet glycoprotein IIb-IIIa receptor with tirofiban resulted in decreased adherence of both $S$. aureus strains by $25 \%$ and $35 \%$, respectively, as compared with bacterial adherence to non-treated platelets. Thus, plasma ligands and platelets promote $S$. aureus adherence to EC. Activated platelets further augmented this process.

\section{Adherence of $\left[{ }^{3} \mathrm{H}\right]$ adenine-labelled platelets to EC}

Washed $\left[{ }^{3} \mathrm{H}\right]$ adenine-labelled platelets were resuspended in autologous plasma and incubated for 20 min with $\mathrm{PGE}_{1} / \mathrm{IBMX}$, PMA, or tirofiban. Platelet adherence to EC under flow $(200 / \mathrm{s})$ conditions was measured (Fig. 4). Platelet inactivation with $\mathrm{PGE}_{1} /$ IBMX did not change platelet binding to EC. However, platelet activation with PMA resulted in an eight-fold increased adherence to EC. In contrast, blockade of platelet glycoprotein IIb-IIIa with tirofiban resulted in a $50 \%$ decrease of platelet adherence to EC compared with intact platelets. These data agree with those 


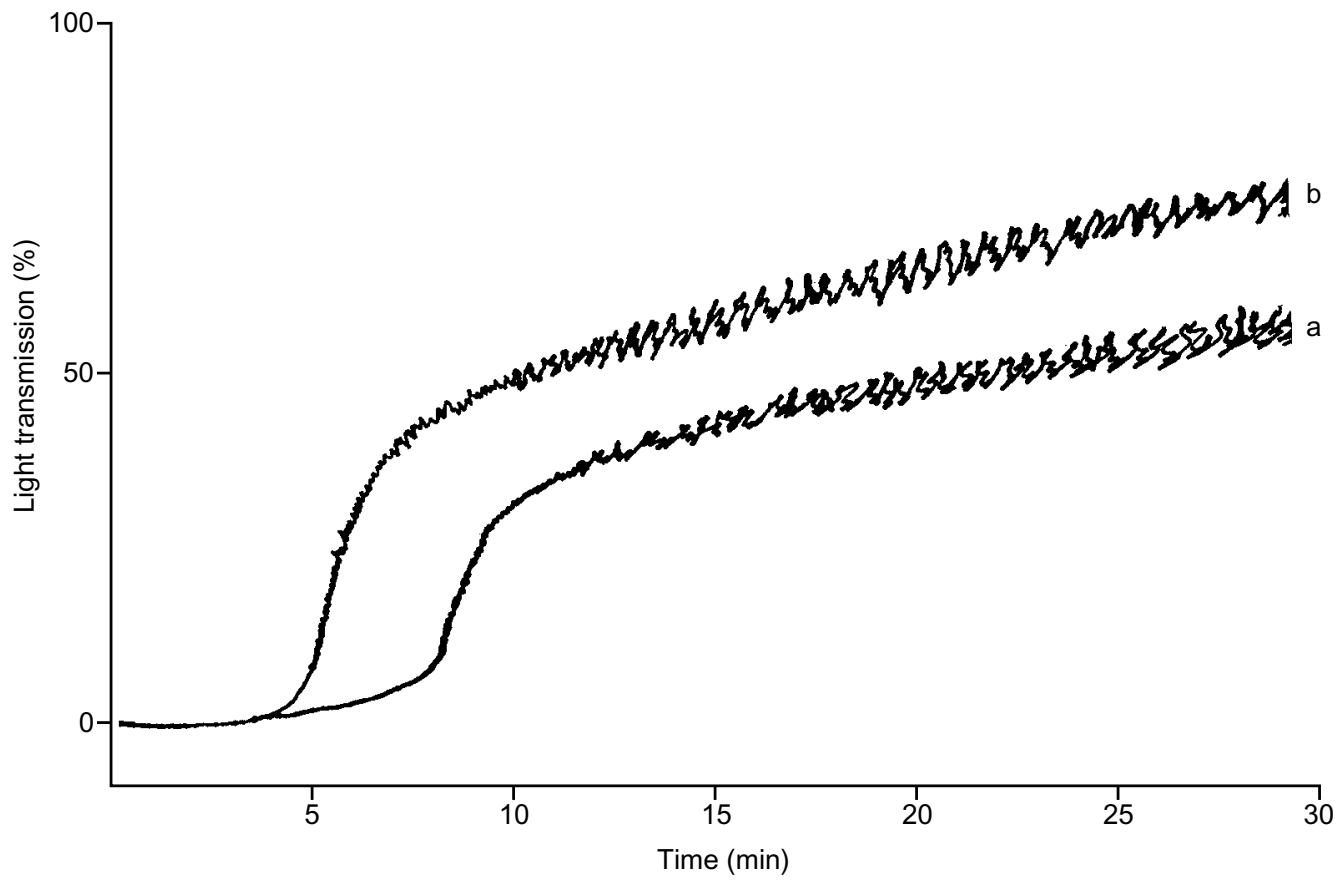

Fig. 2. S. aureus-induced platelet aggregation. Parental strain (a) or RNAIII mutant (b) S. aureus, suspended in PBS, was added to platelet-rich plasma (PRP) (1:10 v:v) at the bacteria:platelet ratio 4:1 in a four-channel platelet aggregometer. Lag phase and change in light transmission were evaluated. Representative picture of three independent experiments.

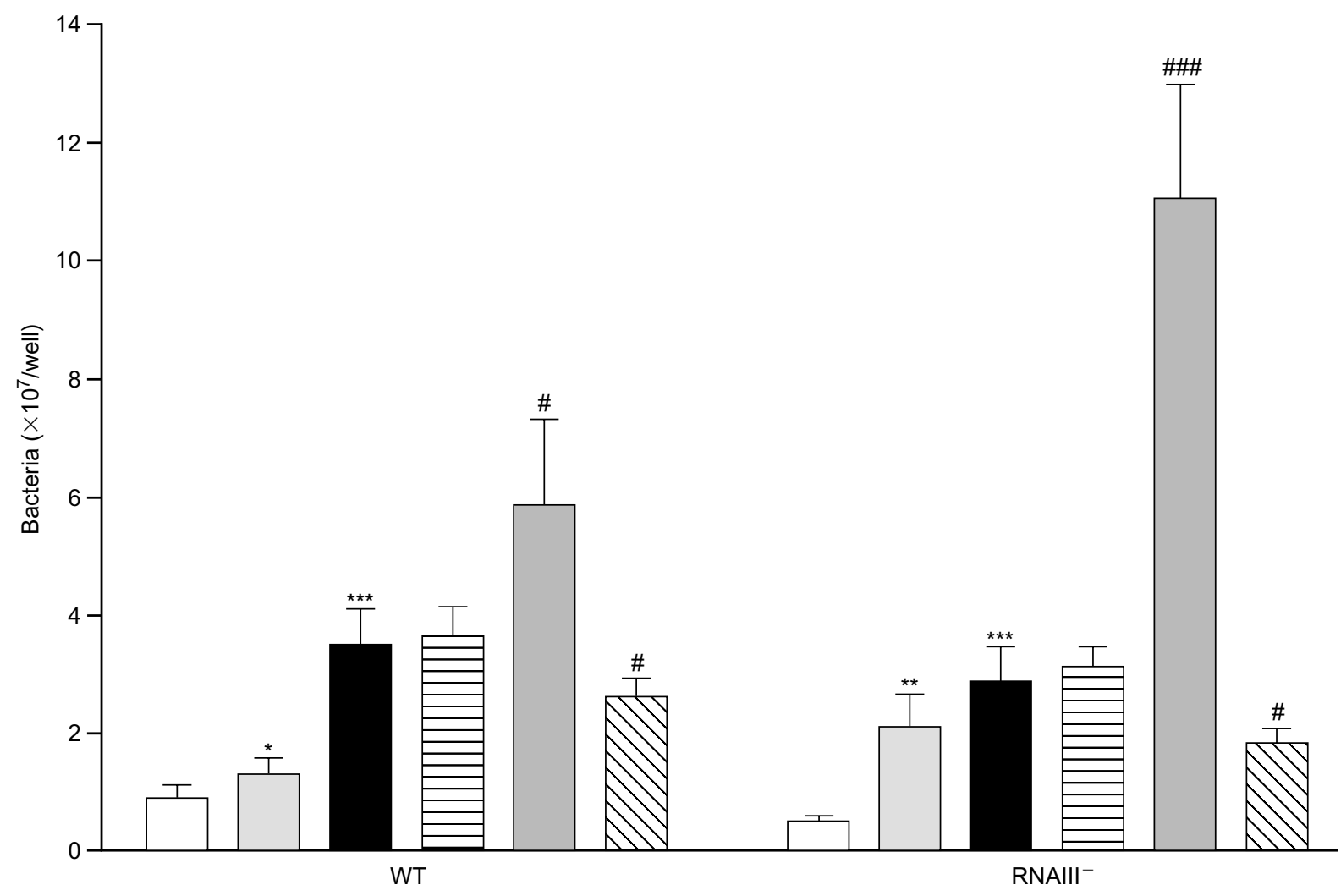

Fig. 3. Adherence of S. aureus to endothelial cells pre-treated with PBS-0.1\% BSA ( $\square$ ), platelet-poor plasma (PPP; $\square$ ) or plateletrich plasma (PRP; $\mathbf{\square})$. Further PRP samples were pre-treated with PBS, $1 \mu \mathrm{M}$ prostaglandin $\mathrm{E}_{1} / 100 \mu \mathrm{M}$ isobutyl-methyl-xantine

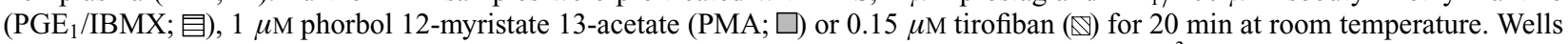
with EC monolayer were incubated with blood components for $20 \mathrm{~min}$ at $37^{\circ} \mathrm{C}$. After washing, $\left[{ }^{3} \mathrm{H}\right]$ thymidine-labelled $S$. aureus $\left(2 \times 10^{8} \mathrm{cfu}\right)$ were placed on the EC surface and incubated for $20 \mathrm{~min}$ at $37^{\circ} \mathrm{C}$ under flow condition $(200 / \mathrm{s})$. Samples were washed and the number of adherent bacteria was measured. Data are mean and SD of 3-5 determinations performed in duplicate. ${ }^{*}$ Compared to EC pre-treated with PBS, \#compared to PRP pre-treated with PBS; ${ }^{*}$ or $\# \mathrm{p}<0.05,{ }^{* *} \mathrm{p}<0.01,{ }^{* * *}$ or $\# \#$ \# $<0.001$. 


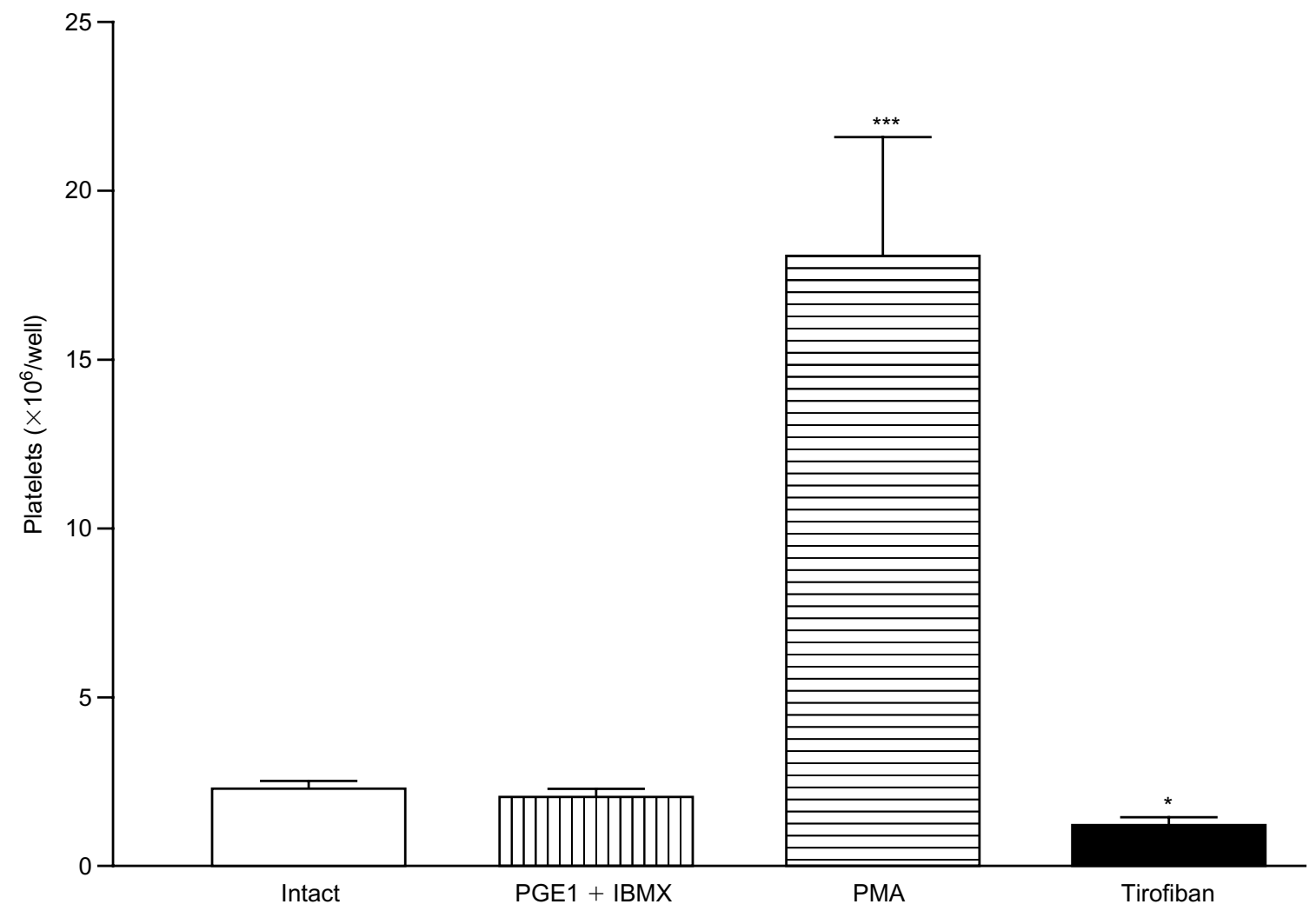

Fig. 4. Adherence of platelets in PRP to EC. $\left[{ }^{3} \mathrm{H}\right]$ Adenine-labelled platelets reconstituted in autologous plasma, $200 \mu 1 /$ well containing (2-4) $\times 10^{7}$ cells), were pre-treated with PBS $(\square), 1 \mu \mathrm{M}$ prostaglandin $\mathrm{E}_{1} / 100 \mu \mathrm{M}$ isobutyl-methyl-xantine (PGE $/$

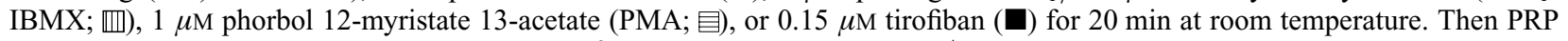
samples were incubated with EC for $20 \mathrm{~min}$ at $37^{\circ} \mathrm{C}$ under flow condition $(200 / \mathrm{s})$. After washing and solubilisation, the number of adherent platelets was measured. ${ }^{*} \mathrm{p}<0.05,{ }^{* * *} \mathrm{p}<0.001$ compared with control (PBS).

demonstrating $S$. aureus adherence to EC pre-treated with modulated platelets in PRP.

\section{Discussion}

The role of RNAIII in the regulation of $S$. aureus adherence to the vessel wall, in which flow and static conditions are compared, has not been reported. In the present study, this question was addressed by using the RNAIII mutant, WA400, in comparison to its parent strain, 8325-4, in their stationary phase. Previously it was shown that ligand-mediated binding of bacteria to the vessel wall might differ under flow compared to static conditions [21]. The present results demonstrated increased adherence of the RNAIII mutant to immobilised fibrinogen under static conditions. Similar results, but under flow conditions, were obtained with the $a g r$ mutant, RN6911 compared to its wild-type, RN6390 [21]. The stronger ability of the RNAIII mutant compared with the wild-type strain to induce platelet aggregation in suspension correlated with increased binding of the mutant to fibrinogen. These results agree with those demonstrating that platelet aggregation by $S$. aureus is mitigated by antibody against staphylococcal fibrinogen-binding protein and is delayed or absent in ClfA-negative strains [24]. It was concluded that $S$. aureus induces platelet aggregation via a fibrinogendependent mechanism.
In contrast to the effect of RNAIII mutation on $S$. aureus adherence to fibrinogen, there was a decreased adherence of the mutant to both fibronectin and EC monolayer (under both static and flow conditions). Taken together, these results suggest that RNAIII decreases $S$. aureus binding to fibrinogen and increases $S$. aureus binding to fibronectin and EC. These data agree with the findings of a diminished fibronectinbinding capacity of both sar and agr/sar mutants of $S$. aureus [21,28]. Fewer bacteria of the double mutant adhered to valvular vegetations in a rabbit model of endocarditis [28]. Accordingly, inactivation of the sar locus resulted in reduced production of both extracellular (haemolysins) and cell wall-binding proteins [29]. Recent studies have highlighted the role of fibronectin-binding proteins (FnBP) of $S$. aureus and EC cell surface fibronectin in bacterial adherence to EC. Both FnBPA and FnBPB are required for bacterial binding and subsequent internalisation by EC [30]. This process is mediated by alpha -beta $_{1}$ integrin [31].

The present study showed reduced adherence of the RNAIII mutant to fibronectin that correlated with a reduced adherence of the RNAIII mutant to EC which appeared in the absence of blood components. When bacterial adherence was assayed after pre-treatment of EC with plasma (free from platelets), greater adherence was observed and it was more pronounced with the mutant than the parental strain. This could be explained 
by the increased binding of the mutant to fibrinogen and by the role of fibrinogen as an important bridging molecule for $S$. aureus adherence to EC $[32,33]$. Pretreatment of EC with platelet-rich plasma further augmented $S$. aureus adherence to EC. Moreover, preactivation of platelets with PMA resulted in an enhanced adherence of the parental strain (1.7-fold) and RNAIII mutant (4-fold) to EC, whereas blockade of the Arg-Gly-Asp domain of platelet glycoprotein IIb-IIIa receptor with tirofiban resulted in reduced adherence of both $S$. aureus types. The modulation of bacterial adherence by platelets can be explained by the change in the number of platelets adhering to EC monolayers. In separate experiments with radiolabelled platelets, an enhanced adherence of PMA-activated platelets and a reduced adherence of glycoprotein IIbIIIa-blocked platelets to EC was found. Adherence of the RNAIII mutant to EC was more susceptible to pretreatment of EC with activated platelets than the wildtype strain. These data can be explained by upregulation and conformational changes of platelet GPIIb-IIIa receptor upon activation leading to fibrinogen binding [34], taking into account the enhanced adherence of the RNAIII mutant to fibrinogen. The results of this and the previous study [21] suggest that the promoting effect of platelets on $S$. aureus adherence to EC is dependent on the number of adherent platelets and available receptors on the platelet membrane. S. aureus may use multiple ligands for binding to both platelets and EC. Deposition of both fibrinogen and fibronectin on the membrane of damaged EC is an important mechanism for tethering circulating platelets to EC. S. aureus adheres to the ligands bound to both platelets and EC. The regulation of adherence properties of $S$. aureus is multifactorial. As seen from this study, RNAIII decreases $S$. aureus adherence to fibrinogen under static conditions and increases $S$. aureus adherence to fibrinonectin and EC under both static and flow conditions.

We thank Professor S. Arvidson, Microbiology and Tumor-biology Center, Karolinska Institute, Stockholm, Sweden, for providing bacterial strains, and Dr C.J. Edgell, Department of Pathology, North Caroline University, Chapel Hill, NC, USA, for providing human endothelial cell line Eahy.926.

\section{References}

1. Foster TJ, Höök M. Surface protein adhesins of Staphylococcus aureus. Trends Microbiol 1998; 6: 484-488.

2. Fröman G, Switalski LM, Speciale P, Höök M. Isolation and characterization of fibronectin receptor from Staphylococcus aureus. J Biol Chem 1987; 262: 6564-6571.

3. McDevitt D, Nanavaty T, House-Pompeo K et al. Characterization of the interaction between the Staphylococcus aureus clumping factor (ClfA) and fibrinogen. Eur J Biochem 1997; 247: 416-424.

4. Ni Eidhin D, Perkins S, Francois P, Vaudaux P, Höök M, Foster TJ. Clumping factor B (ClfB), a new surface-located fibrinogen-binding adhesin of Staphylococcus aureus. Mol Microbiol 1998; 30: 245-257.

5. Hartleib J, Köhler N, Dickinson RB et al. Protein A is the von Willebrand factor binding protein on Staphylococcus aureus. Blood 2000; 96: 2149-2156.
6. Morfeldt E, Taylor D, von Gabain A, Arvidson S. Activation of alpha-toxin translation in Staphylococcus aureus by the trans-encoded antisense RNA, RNAIII. EMBO $J$ 1995; 14: 4569-4577.

7. Recsei P, Kreiswirth B, O'Reilly M, Schlievert P, Gruss A, Novick RP. Regulation of exoprotein gene expression in Staphylococcus aureus by agr. Mol Gen Genet 1986; 202: 58-61.

8. Novick RP, Ross HF, Projan SJ, Kornblum J, Kreiswirth B, Moghazeh S. Synthesis of staphylococcal virulence factors is controlled by a regulatory RNA molecule. EMBO J 1993; 12: 3967-3975.

9. Chien Y-T, Manna AC, Cheung AL. SarA level is a determinant of agr activation in Staphylococcus aureus. Mol Microbiol 1998; 30: 991-1001.

10. Heinrichs JH, Bayer MG, Cheung AL. Characterization of the sar locus and its interaction with agr in Staphylococcus aureus. J Bacteriol 1996; 178: 418-423.

11. Manna AC, Bayer MG, Cheung AL. Transcriptional analysis of different promoters in the sar locus in Staphylococcus aureus. $J$ Bacteriol 1998; 180: 3828-3836.

12. Cheung AL, Koomey JM, Butler CA, Projan SJ, Fischetti VA. Regulation of exoprotein expression in Staphylococcus aureus by a locus (sar) distinct from agr. Proc Natl Acad Sci USA 1992; 89: 6462-6466.

13. Balaban N, Novick RP. Autocrine regulation of toxin synthesis by Staphylococcus aureus. Proc Natl Acad Sci USA 1995; 92: 1619-1623.

14. Clawson CC. The role of platelets in the pathogenesis of endocarditis. American Heart Association Monograph 1979; 52: 24-27.

15. Scheld WM, Valone JA, Sande MA. Bacterial adherence in the pathogenesis of endocarditis: interaction of bacterial dextran, platelets and fibrin. J Clin Invest 1978; 61: 1394-1404.

16. Nicolau DP, Freeman CD, Nightingale $\mathrm{CH}$ et al. Reduction of bacterial titers by low-dose aspirin in experimental aortic valve endocarditis. Infect Immun 1993; 61: 1593-1595.

17. Clawson CC, White JG. Platelet interaction with bacteria. II. Fate of the bacteria. Am J Pathol 1971; 65: 381-397.

18. Yeaman MR, Tang Y-Q, Shen AJ, Bayer AS, Selsted ME. Purification and in vitro activities of rabbit platelet microbicidal proteins. Infect Immun 1997; 65: 1023-1031.

19. Yeaman MR, Bayer AS. Antimicrobial peptides from platelets. Drug Resistance Updates 1999; 2: 116-126.

20. Janzon L, Arvidson S. The role of the delta-lysin gene $(h l d)$ in the regulation of virulence genes by the accessory gene regulator (agr) in Staphylococcus aureus. EMBO J 1990; 9: 1391-1399.

21. Shenkman B, Rubinstein E, Cheung AL et al. Adherence properties of Staphylococcus aureus under static and flow conditions: the role of $a g r$ and sar loci as well as of platelets and plasma ligands. Infect Immun 2001; 69: 4473-4478.

22. Edgell CJ, McDonald CC, Graham JB. Permanent cell line expressing factor VIII-related antigen established by hybridization. Proc Natl Acad Sci USA 1983; 80: 3734-3737.

23. Varon D, Dardik R, Shenkman B et al. A new method for quantitative analysis of whole blood platelet interaction with extracellular matrix under flow conditions. Thromb Res 1997; 85: $283-294$.

24. Bayer AS, Sullam PM, Ramos M, Cong Li, Cheung AL, Yeaman MR. Staphylococcus aureus induces platelet aggregation via a fibrinogen-dependent mechanism which is independent of principal platelet glycoprotein IIb/IIIa fibrinogenbinding domains. Infect Immun 1995; 63: 3634-3641.

25. Maurice DH, Haslam RJ. Molecular basis of the synergistic inhibition of platelet function by nitrovasodilators and activators of adenylate cyclase: inhibition of cyclic AMP breakdown by cyclic GMP. Mol Pharmacol 1990; 37: 671-681.

26. Hartwig JH, Kung S, Kovacsovics T et al. D3 phosphoinositides and outside-in integrin signaling by glycoprotein IIb-IIIa mediate platelet actin assembly and filopodial extension induced by phorbol 12-myristate 13-acetate. J Biol Chem 1996; 271:32986-32993.

27. Cohen M, Théroux P, Weber S et al. Combination therapy with tirofiban and enoxaparin in acute coronary syndromes. Int $J$ Cardiol 1999; 71: 273-281.

28. Cheung AL, Eberhardt KJ, Chung E et al. Diminished virulence of a sar ${ }^{-} /$agr $r^{-}$mutant of Staphylococcus aureus in the rabbit model of endocarditis. J Clin Invest 1994; 94: 1815-1822. 
29. Kornblum J, Kreiswirth B, Projan SJ, Ross H, Novick RP. Agr a polycistronic locus regulating exoprotein synthesis in Staphylococcus aureus. In: Novick RP (ed) Molecular biology of the staphylococci. New York, VCH Publishers. 1990: 373-402.

30. Peacock SJ, Foster TJ, Cameron BJ, Berendt AR. Bacterial fibronectin-binding proteins and endothelial cell surface fibronectin mediate adherence of Staphylococcus aureus to resting human endothelial cells. Microbiology 1999; 145: 3477-3486.

31. Massey RC, Kantzanou MN, Fowler $\mathrm{T}$ et al. Fibronectinbinding protein A of Staphylococcus aureus has multiple, substituting, binding regions that mediate adherence to fibronectin and invasion of endothelial cells. Cell Microbiol 2001; 3: 839-851.

32. Cheung AL, Krishnan M, Jaffe EA, Fischetti VA. Fibrinogen acts as a bridging molecule in the adherence of Staphylococcus aureus to cultured human endothelial cells. J Clin Invest 1991; 87: 2236-2245.

33. Shenkman B, Rubinstein E, Tamarin I, Dardik R, Savion N, Varon D. Staphylococcus aureus adherence to thrombin-treated endothelial cells is mediated by fibrinogen but not by platelets. $J$ Lab Clin Med 2000; 135: 43-51.

34. White JG, Escolar G. Current concepts of platelet membrane response to surface activation. Platelets 1993; 4: $175-189$. 